\title{
First record of Cylindrotoma distinctissima (Meigen, 1818) from Serbia and new data on the occurrence of Cylindrotomidae (Diptera) in Bulgaria and Romania
}

\author{
Levente-Péter KOLCSÁR ${ }^{1}$, Edina TÖRÖK ${ }^{1,2}$ and Lujza KERESZTES ${ }^{1}$ \\ ${ }^{1}$ Hungarian Department of Biology and Ecology, Centre of Systems Biology, Biodiversity and Biorecourses, University \\ of Babess-Bolyai Cluj-Napoca, Clinicilor 5-7, Romania; e-mail: kolcsar.peter@gmail.com (corresponding author) \\ ${ }^{2}$ Romanian Academy Institute of Biology, Splaiul Independenței 296, 060031 Bucureşti, Romania; \\ e-mail: edinatorok7@gmail.com
}

\begin{abstract}
Here we present the first records of Cylindrotoma distinctissima distinctissima (Meigen, 1818) from Serbia, which represents a new family (Cylindrotomidae, Diptera) to the dipteran fauna of the country. Additionally, new records on this species are given from Bulgaria and Romania. New records of two other rare species of Cylindrotomidae, i.e. Diogma glabrata (Meigen, 1818) and Triogma trisulcata Schummel, 1829) are listed from Romania.
\end{abstract}

Key words: words: long-bodied craneflies, occurrence, Tipuloidea, Diogma glabrata, Triogma trisulcata

\section{INTRODUCTION}

Cylindrotomidae or long-bodied crane flies are a small diptera family, within Tipuloidea. Currently, 70 recognized species are known worldwide, from which eight species are reported from West Palaearctic (Paramonov 2005, Oosterbroek 2018, Salmela 2013). Most of the European species only occur in the northern part of Europe, nevertheless Cylindrotoma distinctissima distinctissima (Meigen, 1818) is the only species that is also reported from the Balkan region (Oosterboek 2017). Presence of Diogma glabrata (Meigen, 1818) and Triogma trisulcata (Schummel, 1829) is less possible in this area.

During a trip in Serbia we collected seven Cylindrotomidae specimens in Kopaonik Mountains, which represent the first records of the family in Serbia. Additional records of long-bodied crane fly species are listed from Bulgaria and Romania.

\section{MATERIAL AND METHODS}

Specimens were collected using sweep nets and were stored in $96 \%$ ethanol (four specimens) or pinned (three specimens) and deposited in Diptera Collection of the Faculty of Biology and Geology, Babeş-Bolyai University, Cluj-Napoca, Romania (DCBBU). The morphological characteristics of the male terminalia were examined after macerated in $\mathrm{KOH}$ $10 \%$. The photos were taken using Olympus SZ61 stereomicroscope equipped with a Canon 650D camera and an LM Digital SLR Adapter (Micro Tech Lab, Austria). Layer photos were combined using free version of Zerene Stacker (http://zerenesystems.com/cms/stacker). Date format: day, month, year. All collection data are available on the TransDiptera Online Database (Kolcsár et al. 2018). 


\section{Cylindrotoma distinctissima distinctissima (Meigen, 1818)}

(Figs 1-5)

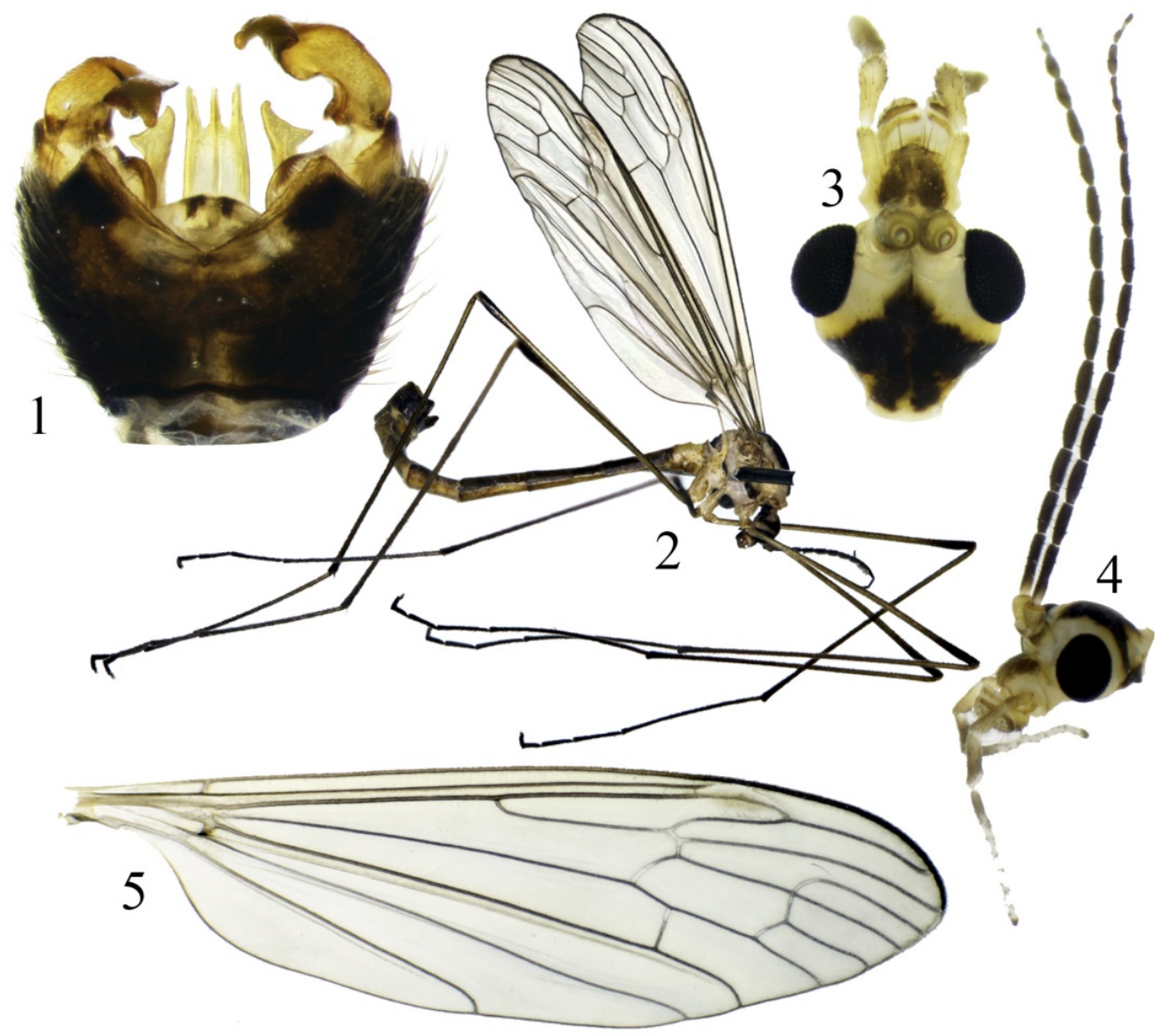

Figs 1-5. Cylindrotoma distinctissima distinctissima (Meigen, 1818) from Kopaonik Mountains (Serbia); 1 - dorsal view of male hypopygium, 2 - habitus, 3 - dorsal view of the head (antennae removed), 4 - lateral view of the head, 5 - wing. Photos by L.-P. Kolcsár.

Material. Bulgaria: Barzia, Stara Planina Mts., Petrohan Pass, 1306 m a.s.l., 43.111397

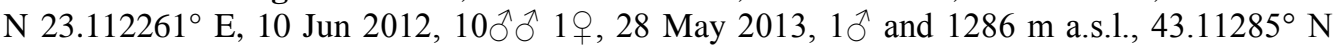
$23.11238^{\circ}$ E, 10 Jun 2012, $3 \widehat{\partial}^{\hat{\jmath}}$, leg. L. Keresztes (LK), E. Török (ET) and L.-P. Kolcsár (LPK).; Kiustendil, Osogovo Mts., Osogovska hut, 1520 m a.s.l., 42.196540 ${ }^{\circ}$ N 22.621927 E,

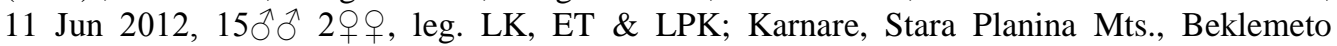

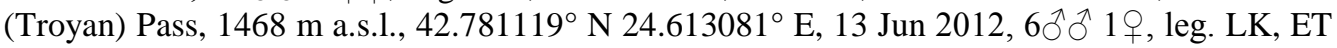
\& LPK; Tvarditsa, Stara Planina Mts., Ciumerna hut, $800 \mathrm{~m}$ a.s.l., $42.771301^{\circ} \mathrm{N} 25.897318^{\circ}$

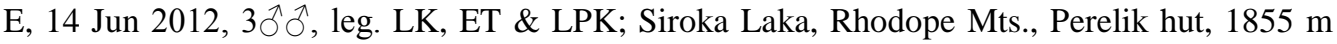
a.s.l., 41.604869 ${ }^{\circ}$ 24.595761 ${ }^{\circ}$ E, 17 Jun 2012, $2{ }^{\lambda}{ }^{\lambda} 1$ 1 , leg. LK, ET \& LPK; Romania: Baia Sprie, Gutâi Mts., Gutâi pass, 990 m a.s.l., 47.694832 N 23.770095 E, 26 May 2012,

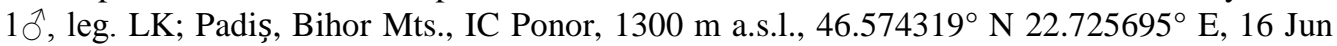


2013, $2 \hat{\jmath} \widehat{\partial}$, leg. L. Keresztes \& A.-L. Dénes; Hagota, Giurgeu Mts., Tisașul Valley, $860 \mathrm{~m}$ a.s.l., 46.861794 ${ }^{\circ}$ N 25.677228 ${ }^{\circ}$ E, 8 Jul 2013, 1 + , leg. LPK; Stâna de Vale, Bihor Mts., Iad

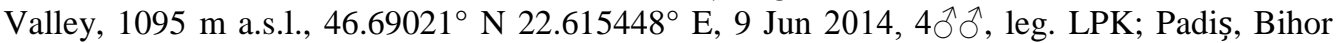

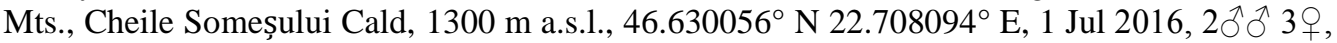
leg. LPK. \& ET; Serbia: between Kopaonik and Jošanička Banja, Kopaonik Mts., $1600 \mathrm{~m}$ a.s.1., $43.298100^{\circ} \mathrm{N} 20.787058^{\circ} \mathrm{E}, 3 \partial^{\lambda} \sigma^{(i n}$ alcohol) and $1556 \mathrm{~m}$ a.s.l., $43.309970^{\circ} \mathrm{N}$ $20.765627^{\circ} \mathrm{E}, 4 \widehat{\delta}^{\lambda}$ (1 in alcohol, 3 pinned), 22 Jun 2017, leg. LPK \& ET.

Habitat. The specimens were collected along small brooks in spruce (Picea abies) dominated forest in Serbia, they were flown close to the ground $(15-20 \mathrm{~cm})$ or rest in ferns close to the brook (Fig. 6).

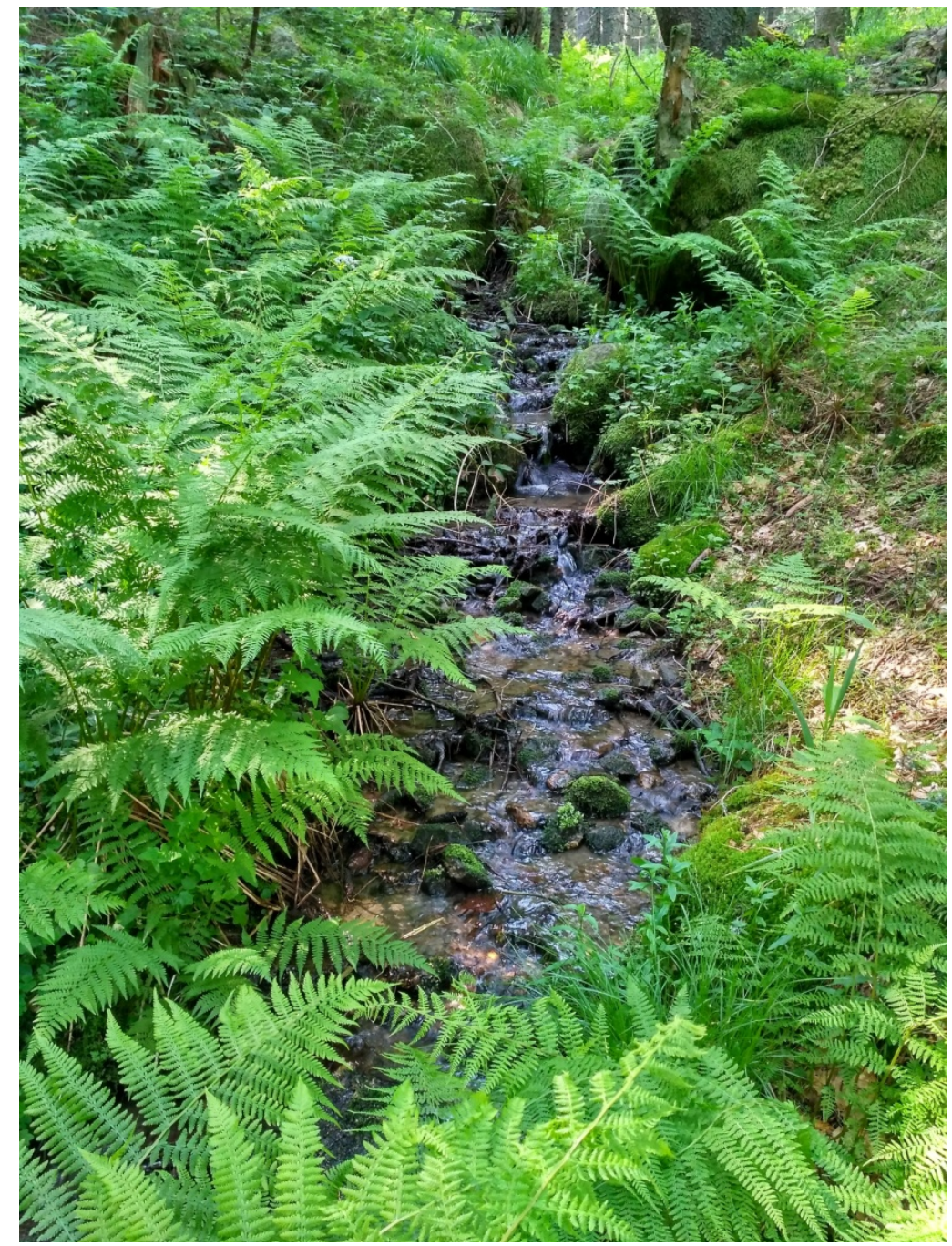

Fig. 6. Habitat where Cylindrotoma distinctissima was found in Serbia. Photos by L.-P. Kolcsár. 
The current distribution of $C$. distinctissima according to the new and the literature data from Bulgaria and Romania (Ujvárosi and Oosterbroek 2002, Ujvárosi et al. 2011) is shown in Fig. 7.

\section{Diogma glabrata (Meigen, 1818)}

Material. Romania: Hagota, Giurgeu Mts., Tisașul Valley, 860 m a.s.l., 46.861794 $\mathrm{N}$ $25.677228^{\circ}$ E, 8 Jul 2013, 19, 17 Jul 2016, 19, leg. LPK; Valea Putnei, Giumalău Mts.,

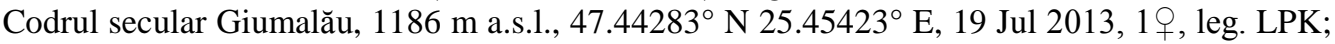
Gura Lalei, Rodnei Mts., Lala Valley, 1200 m a.s.l., 47.545984 N 24.930069 E, 20 Jul 2013 $1{ }^{\lambda} 4$ 우, leg. LPK \& LK.

The current distribution of D. glabrata according to the new and the literature data from Romania (Ujvárosi et al. 2011) is illustrated in Fig. 8.

\section{Triogma trisulcata (Schummel, 1829)}

Material. Romania: Baia Sprie, Gutâi Mts., Gutâi pass, 990 m a.s.l., 47.694832 N 23.770095 E, 15 May 2013, 1§, leg. LPK.

The current distribution of $T$. trisulcata according to the new and the literature data from Romania (Ujvárosi 2005) is shown in Fig. 8.

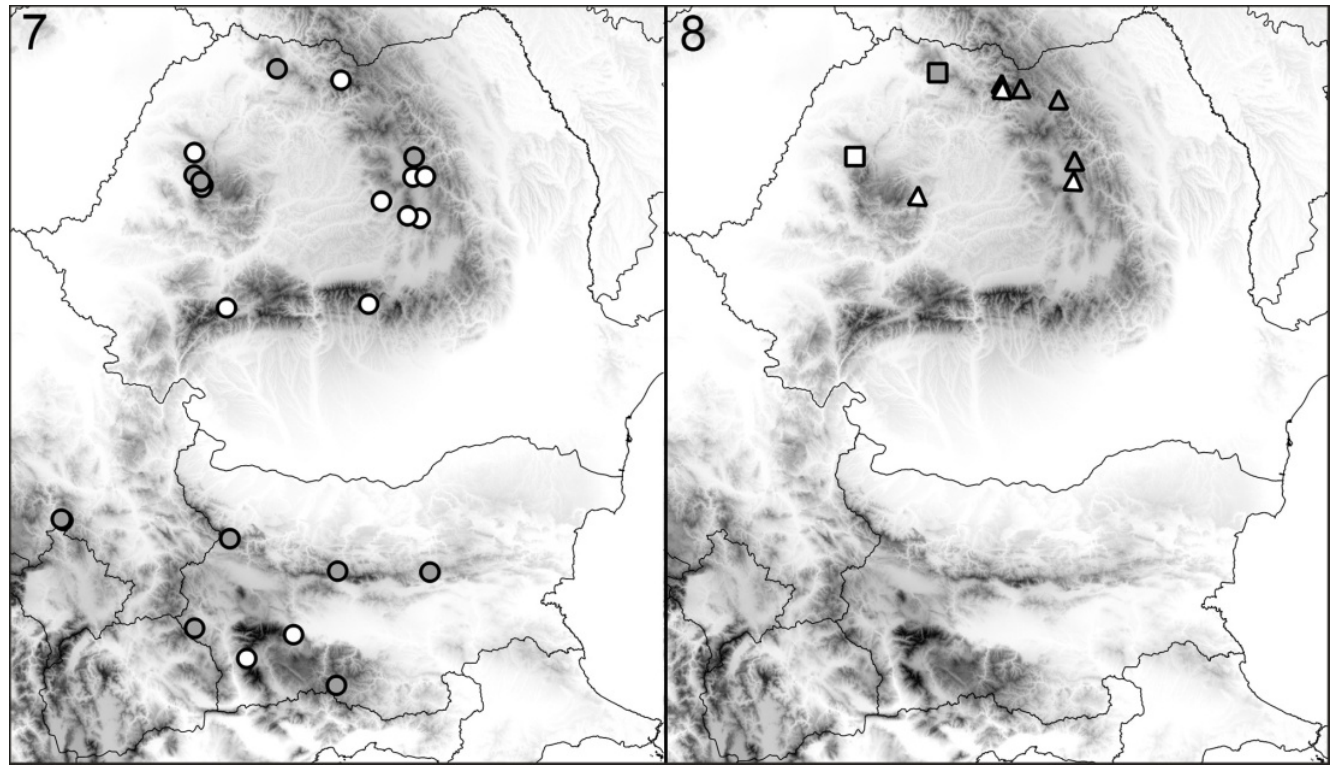

Figs 7 \& 8.7 - Occurrence of Cylindrotoma distinctissima distinctissima) in Bulgaria, Romania and Serbia; white cirlces - literature data, grey circles - new records. 8 - Occurrence of Diogma glabrata (triangles) and Triogma trisulcata (squares) in Romania; white and gray color applies respectively to literature data and new records.

\section{DISCUSSION}

Cylindrotoma distinctissima distinctissima is widely distributed in the Paleartic area and is more common in the northern part of Europe (Oosterbroek 2018). In Central and South Europe the species has insularly distribution in humid mountainous area (Ujvárosi and Oosterbroek 2002, Ujvárosi et al. 2011). The species was previously reported from the following neighbouring countries: Bulgaria (Ujvárosi et al. 2011), Croatia (Langhoffer 1917), Hungary 
(Starý 2001) and Romania (Ujvárosi and Oosterbroek 2002). The species is rather variable in the body colour and genitalia structure in its range (Brodo 1967, Peus 1952, Salmela and Autio 2007, Ujvárosi et al. 2011). Cylindrotoma borealis Peus, 1952 (previously subspecies of C. distinctissima) was recently raised to species rank (Salmela and Autio 2007) and later synonymized with the nominotypical subspecies (C. $d$. distinctissima) based on DNA barcoding results (Salmela 2013). The Italian Alps endemic subspecies C. distinctissima alpestris Peus, 1952 recently raised to species rank as Cylindrotoma alpestris (Oosterbroek 2018). Larvae of $C$. d. distinctissima are terrestrial and phytophagous. Feeding on different higher plants, such as Acer, Allium, Anemone, Caltha, Cirsium kamtschaticum, Maianthemum dilalatum, Ranunculus, Sanicula, Saussurea pseudo-tilesii Stellaria, Trientalis europeae arctica, Trollius, Valeriana and Viola (Peus 1952, Brinkmann 1991, Paramonov and Lobkova 2013).

Presence of $C$. distinctissima is probable in Kosovo since the specimens were collected close to the Serbian-Kosovo border, and the Kopaonik Mountains are continuing in the territory of Kosovo. Furthermore the species occurrence in Greece and Republic of Macedonia is also probable since the specimens were collected just a few kilometre from Greek-Bulgarian and Macedonian-Bulgarian borders (Fig. 7).

Diogma glabrata and Triogma trisulcata are rare species in Central and Southern parts of Europe. Only a few records are known from Carpathians (Fig. 8). All specimens collected near small brooks.

\section{ACKNOWLEDGEMENTS}

We thank Tamara Szentiványi for the linguistic revision and the comments and advice of anonymous reviewers and the help of the editor.

\section{REFERENCES}

BRINKMANN R. 1991. Zur Habitatpräferenz und Phänologie der Limoniidae, Tipulidae und Cylindrotomidae (Diptera) im Bereich eines norddeutschen Tieflandbaches. Faunistisch-Ökologische Mitteilungen Supplement 11: 1-156.

Brodo F. 1967. A review of the subfamily Cylindrotominae in North America (Diptera, Tipulidae). The University of Kansas Science Bulletin 47: 71-115.

Kolcsár L.-P., Veres R. \& KereszTes L. 2018. TransDiptera Online Database. Accessed at: http://transdiptera.ro [Accessed 22 January 2018]. DOI: 10.18426/obm.5sskmlll3ip0

LANGHOFFER A. 1917. Beiträge zur Dipteren-Fauna Kroatiens. Glasnik Hrvatskog Prirodoslovnog Drustva 29: 49-53.

Oosterbroek P. 2018. Catalogue of the Craneflies of the World (Diptera, Tipuloidea: Pediciidae, Limoniidae, Cylindrotomidae, Tipulidae). Available at: http://ccw.naturalis.nl/index.php. [Accessed 22 January 2018]

Paramonov N. M. 2005. Diogma dmitrii sp. n., a new species of cylindrotomid crane-flies (Diptera, Cylindrotomidae) from the Caucasus. Entomological Review 85: 209-211.

PARAMONOV N. M. \& LOBKOVA L.E. 2013. New host plants for larvae of Cylindrotoma distinctissima distinctissima (Meigen, 1818) (Diptera: Cylindrotomidae). Far Eastern Entomologist 258: 6-8.

PEUS F. 1952. Cylindrotomidae. In: LINDNER E. (ed.), Die Fliegen der palaearktischen Region, 3(5)3, Lief. 169 : 1-80.

SALMELA J. 2013. Taxonomy, species richness and biogeography of Finnish crane flies (Diptera, Tipuloidea). Thesis University of Turku, Finland. Annales Universitatis Turkuensis (Series AII) 276: 1-41.

SAlmela J. \& Autio O. 2007 Semiaquatic flies of Kivineva mire, middle boreal Finland, and redescription of Cylindrotoma borealis Peus, 1952 stat. n. (Diptera, Nematocera). An International Journal of Dipterological Research 18: 47-55.

StARÝ J. 2001. Faunistic records of Limoniidae, Pediciidae and Cylindrotomidae (Diptera) from Hungary. Folia Entomologica Hungarica 62: 199-204.

UJVÁRosi L. 2005. Additions to the Cylindrotomidae, Limoniidae and Pediciidae species (Diptera) in Romania and Bulgaria. Entomologica Romanica 10: 65-70.

UjvÁrosi L. \& Oosterbroek P. 2002. The family Cylindrotomidae new to the Romanian fauna (Diptera, Tipuloidea). In: TOMEscu N. \& POPA V. (eds), In memoriam Professor dr. doc. Vasile Gh. Radu. Cluj University Press: 43-45.

UjVÁRosi L., KolCSÁR L.-P. \& VAIDA R. 2011. Additions to the Cylindrotomidae (Insecta, Diptera) fauna of Bulgaria and Romania. Entomologica Romanica 16: 47-50. 


\section{STRESZCZENIE}

[Pierwsze stwierdzenie Cylindrotoma distinctissima (Meigen, 1818) w Serbii oraz nowe dane o występowaniu Cylindrotomidae (Diptera) w Bulgarii i Rumunii]

Artykuł prezentuje pierwsze stwierdzenie Cylindrotoma distinctissima distinctissima (Meigen, 1818) z Serbii, gatunku z rodziny Cylindrotomidae (Diptera), której przedstawicieli nie dotychczas nie wykazywano $\mathrm{z}$ tego kraju. Poza tym, podano nowe stwierdzenia tego gatunku z Bułgarii i Rumunii, gdzie gatunek jest rzadki a także nowe stwierdzenia z Rumunii dwóch innych przedstawicieli Cylindrotomidae, tj. Diogma glabrata (Meigen, 1818) and Triogma trisulcata Schummel, 1829).

Accepted: 24 January 2018 